\title{
Article \\ Prevalence of High Bleeding Risk among Hospitalized Suspected NSTEMI Patients
}

\author{
Henri Kesti ${ }^{1,2, *}$, Henna Mäkinen ${ }^{2,3}$, Kalle Mattila $^{2,3}$, Samuli Jaakkola ${ }^{1} \mathbb{D}$, Mikko Lintu $^{2}$ and Pekka Porela ${ }^{1}$ \\ 1 Heart Centre, Turku University Hospital and University of Turku, 20521 Turku, Finland; \\ samuli.jaakkola@tyks.fi (S.J.); pekka.porela@tyks.fi (P.P.) \\ 2 Emergency Department, Turku University Hospital, 20521 Turku, Finland; \\ henna.m.makinen@utu.fi (H.M.); kalle.matias.mattila@tyks.fi (K.M.); mikko.lintu@tyks.fi (M.L.) \\ 3 Faculty of Medicine, University of Turku, 20014 Turku, Finland \\ * Correspondence: henri.m.kesti@utu.fi; Tel.: +358-40-088-7763
}

Citation: Kesti, H.; Mäkinen, H.; Mattila, K.; Jaakkola, S.; Lintu, M. Porela, P. Prevalence of High Bleeding Risk among Hospitalized Suspected NSTEMI Patients. J. Clin. Med. 2022, 11, 1324. https://doi.org/ $10.3390 /$ jcm 11051324

Academic Editor: Francesco

Giallauria

Received: 15 January 2022

Accepted: 26 February 2022

Published: 28 February 2022

Publisher's Note: MDPI stays neutral with regard to jurisdictional claims in published maps and institutional affiliations.

Copyright: (C) 2022 by the authors. Licensee MDPI, Basel, Switzerland. This article is an open access article distributed under the terms and conditions of the Creative Commons Attribution (CC BY) license (https:// creativecommons.org/licenses/by/ $4.0 /)$

\begin{abstract}
In recent years, guidelines for the management of acute coronary syndromes (ACS) have placed more emphasis on identifying patients at high bleeding risk (HBR). We set out to investigate the prevalence of HBR patients according to the Academic Research Consortium for High Bleeding Risk (ARC-HBR) criteria in hospitalized patients with suspected non-ST-segment elevation myocardial infarction (NSTEMI). Consecutive patients were retrospectively enrolled between January and June 2019 from the emergency department (ED) of a tertiary hospital. The discharge diagnosis and baseline data were manually collected using electronic patient records and database searches. Patients with non-cardiac diagnoses were excluded. Overall, 212 patients were included in the study. A total of $146(68.9 \%)$ patients were diagnosed with NSTEMI (Type 1), 47 (22.2\%) with unstable angina pectoris (UAP) and $19(9.0 \%)$ with "other." HBR was detected in $47.6 \%(n=101)$ of all patients. Common criteria for HBR among ACS patients were age (40.4\%), chronic kidney disease $(33.7 \%)$, and the use of oral anticoagulation medicines (20.2\%). In conclusion, nearly half of the patients hospitalized for ACS fulfilled HBR criteria. According to contemporary guidelines, the management of HBR patients differs from that of non-HBR patients, and thus, a more comprehensive screening for HBR may be considered in clinical practice.
\end{abstract}

Keywords: non-ST-segment elevation myocardial infarction; bleeding; high bleeding risk; Academic Research Consortium

\section{Introduction}

The benefit of dual antiplatelet therapy (DAPT) in reducing further thrombotic events in acute coronary syndromes (ACS) after percutaneous coronary intervention (PCI) is well established by numerous studies [1-5]. However, it comes with a price of increased bleeding complications $[2,5,6]$.

Identifying patients at high bleeding risk (HBR) in this group could be important in reducing bleeding complications associated with ACS management. Major bleeding has been shown to be an independent predictor for mortality, equaling the risk associated with ischemic complications [7-11]. Thus, the choice of treatment should be decided upon based on both the ischemic risk and the bleeding risk of the individual patient [11-13]. A recent study demonstrated that the clinical presentation of ACS per se predicts increased bleeding risk, as compared to chronic coronary syndrome, further emphasizing the importance of considering these two aspects during decision making [14].

In their most recent guideline for the management of non-ST-segment elevation acute coronary syndromes (NSTE-ACS) [13], the European Society of Cardiology (ESC) proposed the use of the Academic Research Consortium for High Bleeding Risk (ARC-HBR) criteria for the identification of HBR patients [15]. The consortium defined HBR as Bleeding Academic Research Consortium (BARC) Type 3 or 5 bleeding risk $\geq 4 \%$ or intracranial 
hemorrhage $\geq 1 \%$ at 1 year [16]. The criteria are separated into major and minor. Even a single major criterion induces the aforementioned bleeding rates, and a minor criterion induces lesser bleeding rates. Patients are at HBR if at least one major or two minor criteria are met.

Most of the data on bleeding events post-PCI comes from DAPT studies or PCI registries. Patients at HBR are often excluded from these studies. Furthermore, due to PCI being an invasive procedure, such registries are selective by nature. The information on the prevalence of HBR and bleeding complication rates among patients with NSTE-ACS is scarce. While there are tools for identifying HBR patients-such as predicting bleeding complications in patients undergoing stent implantation and subsequent dual antiplatelet therapy (PRECISE-DAPT) score [17]—-these have not been properly utilized in daily clinical practice. The aim of this study was to investigate how many of the NSTE-ACS patients fulfilled ARC-HBR criteria for high bleeding risk in an unselected, non-register-based patient population.

\section{Materials and Methods}

The study population consisted of patients who were admitted to the emergency department (ED) due to "chest pain" between 1 January 2019 and 30 June 2019. Admission data was collected using the patient-information system Safir Spider, version 2.22.101.2461 (San Sai Solutions Oy, Turku, Finland), used by the ED at Turku University Hospital (Turku, Finland). If a patient had several visits, only the first one was registered. Only one NSTE-ACS event was reported per patient. We included all consecutive patients with suspected non-ST-segment elevation myocardial infarction (NSTEMI) (age $\geq 18$ years) who were hospitalized. The primary discharge diagnosis was manually evaluated by the authors using electronic patient records and a database search conducted by Auria Clinical Informatics. The search identified a total of 2562 patients, 432 of whom were hospitalized, and after selecting those with NSTEMI and unstable angina pectoris (UAP) diagnosis codes, 212 patients were included in this study. Patients with non-cardiac diagnosis were excluded. The fourth universal definition of myocardial infarction (MI) was used to differentiate between Type 1 and Type 2 MIs [18]. In this study, patients with Type 2 MI were separated from the NSTE-ACS and NSTEMI groups.

Auria Clinical Informatics is an information service provider operating in connection with The Hospital District of Southwest Finland. The service was used to obtain information on dates of emergency department visits, relevant ICD-10 diagnosis codes and procedure codes (during the visits and within the following 60 days), relevant laboratory values during the hospitalization episode, and long-term diagnosis codes that were valid at the time of the visits.

ARC-HBR criteria were manually evaluated by the authors using the aforementioned methods. Relevant time periods were evaluated based on the date of hospitalization. Patients were defined as being at HBR if at least one major or two minor ARC-HBR criteria were met. Major and minor criteria were defined as follows: age $\geq 75$ years (minor); use of oral anticoagulation (OAC) at discharge (major); severe or end-stage chronic kidney disease (CKD) with estimated glomerular filtration rate (eGFR (CKD-EPI formula)) $<30 \mathrm{~mL} / \mathrm{min}$ (major); moderate CKD with eGFR $\geq 30,<60 \mathrm{~mL} / \mathrm{min}$ (minor); hemoglobin $<11 \mathrm{~g} / \mathrm{dL}$ at baseline (major); hemoglobin $\geq 11 \mathrm{~g} / \mathrm{dL},<13 \mathrm{~g} / \mathrm{dL}$ at baseline for men and $\geq 11 \mathrm{~g} / \mathrm{dL}$, $<12 \mathrm{~g} / \mathrm{dL}$ at baseline for women (minor); spontaneous non-intracranial bleeding requiring hospitalization or transfusion in the past 6 months or at any time if recurrent (major); spontaneous non-intracranial bleeding requiring hospitalization or transfusion within the past 12 months not meeting the major criterion (minor); platelet count $<100 \times 10^{9} / \mathrm{L}$ at baseline (major); chronic bleeding diathesis (major); liver cirrhosis with portal hypertension (major); long-term use of oral non-steroidal anti-inflammatory drugs (NSAIDs) or steroids (minor); cancer diagnosis within 12 months (excluding non-melanoma skin cancer) and/or ongoing requirement for treatment (major); previous spontaneous intracranial hemorrhage $(\mathrm{ICH})$ at any time, previous traumatic ICH within the past 12 months, ischemic stroke 
within the past 6 months, presence of brain arteriovenous malformation (major); any ischemic stroke at any time not meeting the major criterion (minor); nondeferrable major surgery on DAPT within 30 days after hospitalization (major); recent major surgery or major trauma within 30 days before hospitalization (major). For one patient, creatinine had not been recorded, resulting in missing eGFR. This patient was at HBR even without considering eGFR and was included in the study population.

Continuous variables are expressed as mean values with standard deviations, and categorical variables are presented as frequencies (percentages). Categorical variables were compared with Pearson's chi-square or Fisher's exact test, as appropriate. The comparison of two mean values for continuous variables was done with an independent samples $t$-test. Normality assumptions were verified using the Kolmogorov-Smirnov test, skewness, and kurtosis. Statistical analyses were performed using SPSS, version 27.0 (SPSS Inc., Chicago, IL, USA).

\section{Results}

The baseline characteristics and prevalence of HBR are shown in Table 1. The primary discharge diagnoses were as follows: 146 (68.9\%) NSTEMI (Type 1), 47 (22.2\%) UAP, $13(6.1 \%)$ NSTEMI (Type 2), and 6 (2.8\%) Takotsubo cardiomyopathy. HBR was detected in $47.6 \%(n=101)$ of patients. In the NSTEMI group, $46.6 \%(n=68)$, and in the UAP group $44.7 \%(n=21)$, were at HBR.

Table 1. Baseline characteristics.

\begin{tabular}{ccccc}
\hline Variable & Total $(\boldsymbol{n = 2 1 2 )}$ & $\begin{array}{c}\text { HBR } \\
(\boldsymbol{n}=\mathbf{1 0 1})\end{array}$ & Non-HBR $(\boldsymbol{n = 1 1 1 )})$ & $\boldsymbol{p}$-Value \\
\hline Age & $71.7 \pm 11.5$ & $78.4 \pm 8.3$ & $65.6 \pm 10.6$ & $<0.001$ \\
\hline Sex & & & & \\
Female & 68 & $40(58.8)$ & $28(41.2)$ & 0.025 \\
Male & 144 & $61(42.4)$ & $83(57.6)$ & 0.025 \\
\hline Clinical presentation & & & & \\
NSTEMI (Type 1) & 146 & $68(46.6)$ & $78(53.4)$ & 0.644 \\
NSTEMI (Type 2) & 13 & $11(84.6)$ & $2(15.4)$ & 0.006 \\
UAP & 47 & $21(44.7)$ & $26(55.3)$ & 0.645 \\
Takotsubo & 6 & $1(16.7)$ & $5(83.3)$ & 0.215 \\
Management & & & & \\
Non-invasive & 43 & $32(74.4)$ & $11(25.6)$ & $<0.001$ \\
PCI & 38 & $16(42.1)$ & $22(57.9)$ & 0.451 \\
CABG & 114 & $49(43.0)$ & $65(57.0)$ & 0.143 \\
Angiography without revascularization & 17 & $4(23.5)$ & $13(76.5)$ & 0.038 \\
\hline
\end{tabular}

Values are $n(\%)$ or mean \pm standard deviation. $p$-values are between HBR group and non-HBR group. NSTEMI: non-ST-segment elevation myocardial infarction; UAP: unstable angina pectoris; Takotsubo: Takotsubo cardiomyopathy; PCI: percutaneous coronary intervention; CABG: coronary artery bypass grafting; HBR: high bleeding risk.

Of the enrolled patients, $32.1 \%(n=68)$ were female. The mean age was 71.7 (standard deviation $(\mathrm{SD}) \pm 11.5$ ) years. Mean age in the HBR group was $78.4(\mathrm{SD} \pm 8.3$ ) years vs. $65.6(\mathrm{SD} \pm 10.6)$ years in the non-HBR group $(p<0.001)$. Additionally, $58.8 \%(n=40)$ of females vs. $42.4 \%(n=61)$ of males were at HBR $(p=0.025)$.

Of all study patients, 53.8\% $(n=114)$ underwent PCI, $8.0 \%(n=17)$ coronary artery bypass grafting $(\mathrm{CABG})$, and $17.9 \%(n=38)$ angiography without revascularization, while $20.3 \%(n=43)$ were assigned to non-invasive management. Non-invasive management was more common in the HBR group than in the non-HBR group $(74.4 \%$ vs. $25.6 \%, p<0.001)$, whereas CABG was more common in the non-HBR group than in the HBR group $(76.5 \%$ vs. $23.5 \%, p=0.038)$. In the PCI group, $43.0 \%(n=49)$ were at HBR vs. $57.0 \%(n=65)$ who were non-HBR $(p=0.143)$. Among those who underwent angiography without PCI or CABG, $42.1 \%(n=16)$ were at HBR vs. $57.9 \%(n=22)$ who were non-HBR $(p=0.451)$.

The prevalence and distribution of different ARC-HBR criteria is shown in Table 2. In NSTE-ACS patients, the most common major criterion was use of OAC $(20.2 \%, n=39)$, 
including direct oral anticoagulants $(n=31)$ and vitamin $\mathrm{K}$ antagonists $(n=8)$. The most common minor and overall criterion was age $\geq 75$ years $(40.4 \%, n=78)$. Other common minor criteria included moderate CKD $(28.0 \%, n=54)$, mild anemia $(18.7 \%, n=36)$, stroke minor $(9.8 \%, n=19)$, and long-term use of p.o. NSAIDs or steroids $(7.3 \%, n=14)$ (none were using NSAIDs). Other common major criteria included severe or end-stage CKD $(5.7 \%, n=11)$ and hemoglobin $<11 \mathrm{~g} / \mathrm{dL}(6.2 \%, n=12)$.

Table 2. Prevalence of ARC-HBR criteria.

\begin{tabular}{|c|c|c|c|c|c|c|c|}
\hline Variable & Total $(n=212)$ & $\begin{array}{l}\text { NSTE-ACS } \\
(n=193)\end{array}$ & $\begin{array}{l}\text { NSTEMI } \\
(n=146)\end{array}$ & $\mathrm{UAP}(n=47)$ & $\begin{array}{c}\text { Age } \geq 75 \\
(n=88)\end{array}$ & $\begin{array}{l}\text { Age } 65-74 \\
(n=71)\end{array}$ & $\begin{array}{c}\text { Age }<65 \\
(n=53)\end{array}$ \\
\hline $\mathrm{OAC}$ & $42(19.8)$ & $39(20.2)$ & $26(17.8)$ & $13(27.7)$ & $30(34.1)$ & $10(14.1)$ & $2(3.8)$ \\
\hline $\begin{array}{l}\text { Severe or end-stage CKD } \\
(\text { eGFR }<30 \mathrm{~mL} / \mathrm{min})\end{array}$ & $14(6.6)$ & $11(5.7)$ & $8(5.5)$ & $3(6.4)$ & $7(8.0)$ & $6(8.5)$ & $1(1.9)$ \\
\hline $\mathrm{Hb}<11 \mathrm{~g} / \mathrm{dL}$ at baseline & $20(9.4)$ & $12(6.2)$ & $9(6.2)$ & $3(6.4)$ & $16(18.2)$ & $2(2.8)$ & $2(3.8)$ \\
\hline $\begin{array}{l}\text { Spontaneous non-ICH bleeding in } \\
\text { the past } 6 \text { months or at any time, } \\
\text { if recurrent* }\end{array}$ & $10(4.7)$ & $5(2.6)$ & $5(3.4)$ & $0(0)$ & $8(9.1)$ & $1(1.4)$ & $1(1.9)$ \\
\hline $\begin{array}{c}\text { Platelet count }<100 \times 10^{9} / \mathrm{L} \\
\text { at baseline }\end{array}$ & $2(0.9)$ & $1(0.5)$ & $1(0.7)$ & $0(0)$ & $2(2.3)$ & $0(0)$ & $0(0)$ \\
\hline Chronic bleeding diathesis & $2(0.9)$ & $2(1.0)$ & $2(1.4)$ & $0(0)$ & $2(2.3)$ & $0(0)$ & $0(0)$ \\
\hline $\begin{array}{l}\text { Liver cirrhosis with portal } \\
\text { hypertension }\end{array}$ & $0(0)$ & $0(0)$ & $0(0)$ & $0(0)$ & $0(0)$ & $0(0)$ & $0(0)$ \\
\hline $\begin{array}{c}\text { Active malignancy within the past } \\
12 \text { months (excluding } \\
\text { nonmelanoma skin cancer) } \S\end{array}$ & $5(2.4)$ & $3(1.6)$ & $3(2.1)$ & $0(0)$ & $5(5.7)$ & $0(0)$ & $0(0)$ \\
\hline $\mathrm{ICH} /$ stroke major + & $2(0.9)$ & $1(0.5)$ & $0(0)$ & $1(2.1)$ & $2(2.3)$ & $0(0)$ & $0(0)$ \\
\hline $\begin{array}{l}\text { Nondeferrable major surgery } \\
\text { on DAPT }\end{array}$ & $0(0)$ & $0(0)$ & $0(0)$ & $0(0)$ & $0(0)$ & $0(0)$ & $0(0)$ \\
\hline $\begin{array}{c}\text { Recent major surgery or major } \\
\text { trauma within } 30 \text { days before } \\
\text { hospitalization }\end{array}$ & $1(0.5)$ & $1(0.5)$ & $1(0.7)$ & $0(0)$ & $0(0)$ & $0(0)$ & $1(1.9)$ \\
\hline Age $\geq 75$ & 88 (41.5) & 78 (40.4) & $56(38.4)$ & $22(46.8)$ & & & \\
\hline $\begin{array}{c}\text { Moderate CKD } \\
\text { (eGFR 30-59.99 } \mathrm{mL} / \mathrm{min})\end{array}$ & $58(27.4)$ & $54(28.0)$ & $43(29.5)$ & $11(23.4)$ & $36(40.9)$ & $19(26.8)$ & $3(5.7)$ \\
\hline $\begin{array}{l}\mathrm{Hb} 11-12.9 \mathrm{~g} / \mathrm{dL} \text { for men and } \\
11-11.9 \mathrm{~g} / \mathrm{dL} \text { for women at baseline }\end{array}$ & 38 (17.9) & $36(18.7)$ & 27 (18.5) & $9(19.1)$ & $20(22.7)$ & $16(22.5)$ & $2(3.8)$ \\
\hline $\begin{array}{l}\text { Spontaneous non-ICH bleeding } \\
\text { within the past } 12 \text { months not } \\
\text { meeting the major criterion * }\end{array}$ & $0(0)$ & $0(0)$ & $0(0)$ & $0(0)$ & $0(0)$ & $0(0)$ & $0(0)$ \\
\hline $\begin{array}{l}\text { Long-term use of p.o. NSAIDs } \\
\text { or steroids }\end{array}$ & $18(8.5)$ & $14(7.3)$ & $12(8.2)$ & $2(4.3)$ & $11(12.5)$ & $4(5.6)$ & $3(5.7)$ \\
\hline $\begin{array}{l}\text { Any ischemic stroke at any time not } \\
\text { meeting the major criterion }\end{array}$ & $19(9.0)$ & $19(9.8)$ & $12(8.2)$ & 7 (14.9) & 12 (13.6) & $7(9.9)$ & $0(0)$ \\
\hline
\end{tabular}

* Requiring hospitalization or transfusion. $\S$ Active malignancy is defined as diagnosis within 12 months and/or ongoing requirement for treatment. † Previous spontaneous ICH (at any time), previous traumatic ICH within the past 12 months, ischemic stroke within the past 6 months. Values are $n(\%)$. OAC: oral anticoagulation (direct oral anticoagulant or vitamin K antagonist); CKD: chronic kidney disease; eGFR: estimated glomerular filtration rate (CKD-EPI formula); Hb: hemoglobin; ICH: intracranial hemorrhage; DAPT: dual antiplatelet therapy; NSAID: non-steroidal anti-inflammatory drug; NSTE-ACS: non-ST-segment elevation acute coronary syndrome (excluding Type 2 myocardial infarctions); NSTEMI: non-ST-segment elevation myocardial infarction (Type 1); UAP: unstable angina pectoris.

\section{Discussion}

Our study indicates that HBR is frequently encountered in this patient group, with almost half of the patients fulfilling ARC-HBR criteria. Notably, high age, use of OAC, moderate $\mathrm{CKD}$, and mild anemia were common constituents of HBR criteria in these patients. Patients at HBR were older, more often female, and non-invasive management 
strategy was more common, as compared to non-HBR patients. Almost all the criteria were more prevalent in older patients.

The prevalence of HBR according to ARC-HBR criteria in studies of European and Asian populations has ranged from $30 \%$ to $50 \%$, and the incidence of major bleeding events in the HBR groups of these studies has consistently been $\geq 4 \%$ at 1 year $[14,19-24]$. The highest major bleeding rates were reported in Korea. HBR was detected in 35.4\% of Korean patients, and the incidence of major bleeding among this group at 1 year was 31.3\% (BARC 3 to 5), even though some HBR factors-such as OAC use-were selected as exclusion criteria [22]. In a study concerning over 16,000 patients from Bern PCI registry, 34.7\% were at HBR, and the incidence of major bleeding at 1 year was 7.9\% (BARC 3 or 5) [19].

Gimbel and colleagues reported a bleeding incidence (PLATO major or minor) of 18\% for clopidogrel versus $24 \%$ for ticagrelor users in patients aged $\geq 70$ years presenting with NSTE-ACS $[25,26]$. In a sub-analysis of OAC users, bleeding rates were $20.9 \%$ and $33.5 \%$, respectively [27]. While the latter are at HBR according to ARC-HBR criteria, the studies vastly excluded patients with increased bleeding risk [28].

In general, the majority of the data on bleeding events post PCI comes from clinical DAPT trials and PCI registries. Since PCI is an invasive procedure, the prevalence of HBR patients could be skewed to the lesser side when the data comes from said registries. In DAPT trials, HBR or some of its underlying constituents are often selected as exclusion criteria. Studies show that bleeding risk gets incrementally higher as risk factors, such as ARC-HBR, accumulate [19-24]. As a result, the prevalence of HBR and actual bleeding rates could be even higher than reported.

In our population, the most frequently encountered criteria were age, CKD, anemia, and use of OAC. Prior stroke and use of p.o. NSAIDs or steroids were moderately prevalent. Previous studies have reported similar results [14,19-24]. OAC-use and age seem to be even more prevalent in Finnish patients, but active malignancy is less frequently encountered. It is noteworthy that several of the minor ARC-HBR criteria in isolation predict a major bleeding incidence $\geq 4 \%$ at 1 year [19-22], particularly age, moderate CKD, and mild anemia, which are also the most prevalent ones.

For NSTE-ACS patients, the ESC guideline recommends that, after coronary stent implantation, DAPT consisting of acetylsalicylic acid (ASA) and a P2Y12 receptor inhibitor, should be continued for 12 months unless there are contraindications [1,2,5]. Discontinuation of a P2Y12 receptor inhibitor after three months should be considered in HBR patients $[12,17]$. According to Costa and colleagues, this also applies to patients with high ischemic risk. Longer-lasting DAPT was only beneficial when HBR was not present [29]. Alternatively, stopping ASA after 3 to 6 months should be considered, based on the balance between ischemic and bleeding risk [30-32]. The recommendation to cease aspirin is supported by recent reports investigating ticagrelor monotherapy after 3 months of DAPT $[33,34]$. Still, these recommendations are based on limited clinical data, and further study of antithrombotic medication in HBR patients is needed. Regarding the choice between clopidogrel and more potent inhibitors, the findings of Gimbel and colleagues suggest that clopidogrel is a better option compared to ticagrelor for $\geq 70$ year-old HBR patients $[25,27]$. Choosing the right thienopyridine and suitable DAPT duration, and thus following current guidelines, requires identification of HBR patients.

Even shorter DAPT durations have recently been investigated. Valgimigli and colleagues concluded that, in HBR patients, 1 month of DAPT followed by 11 months of single antiplatelet therapy (SAPT) was non-inferior to at least 3 months of DAPT followed by SAPT regarding net adverse clinical events and resulted in lower incidence of major bleeding [35]. In the 1-month DAPT group, about 54\% used clopidogrel monotherapy, and only about half the patients had an ACS. In a study enrolling exclusively ACS patients, however, 1 month of DAPT followed by 11 months of SAPT using clopidogrel failed to prove non-inferiority to 12 months of DAPT for net clinical benefit [36]. These studies were not focused on NSTE-ACS and had different patient demographics. The latter was focused on ACS but had 56\% ST-segment elevation myocardial infarction patients, while the former 
had only about $12 \%$ and was focused on HBR patients. Different stent types were also used. It remains unclear whether 1-month DAPT is sufficient in NSTE-ACS.

Our study has some limitations. First, it was a retrospective study. Evaluation of the discharge diagnoses was done retrospectively, and thus, the investigators were reliant on the treating physicians. Second, it was a single-center study with a limited number of patients, which impairs the generalizability of the results. However, previous studies have reported similar prevalence rates.

In conclusion, HBR is frequently encountered in clinical practice, and more comprehensive screening is necessary for proper management of NSTE-ACS. The prevalence of $\mathrm{HBR}$ and bleeding rates should be investigated in a multi-center, prospective approach.

Author Contributions: Conceptualization, H.K. and P.P.; methodology, H.K. and P.P.; software, H.K. and K.M.; validation, H.K. and K.M.; formal analysis, H.K. and K.M.; investigation, H.K., H.M., P.P., and M.L.; resources, H.K. and H.M.; data curation, H.K. and H.M.; writing-original draft preparation, H.K. and H.M.; writing-review and editing, H.K., P.P., S.J., K.M., and M.L.; visualization, H.K.; supervision, P.P.; project administration, P.P. All authors have read and agreed to the published version of the manuscript.

Funding: The article processing charge was funded by State Research Funding from the Hospital District of Southwest Finland.

Institutional Review Board Statement: This study was approved by the Institutional Review Board of the Hospital District of Southwest Finland (T90/2020). Ethical review was waived for this study due to its retrospective nature. According to the Finnish Medical Research Act (https: / www.finlex. fi/fi/laki/ajantasa/1999/19990488, accessed on 14 January 2022), ethical review is not required for retrospective studies. Nevertheless, this study complies with the guideline of the Finnish Advisory Board on Research Integrity (appointed by the Ministry of Education and Culture in Finland [Decree 1347/1991]), Responsible conduct of research and procedures for handling allegations of misconduct in Finland, 14 November 2012 (https: / tenk.fi/sites/tenk.fi/files/HTK_ohje_2012.pdf, accessed on 14 January 2022).

Informed Consent Statement: Informed consent was not required because of the observational nature of this study.

Data Availability Statement: All data are available upon reasonable request by contacting the corresponding author.

Conflicts of Interest: The authors declare no conflict of interest.

\section{References}

1. Wallentin, L.; Becker, R.C.; Budaj, A.; Cannon, C.P.; Emanuelsson, H. Ticagrelor versus Clopidogrel in Patients with Acute Coronary Syndromes. N. Engl. J. Med. 2009, 361, 1045-1057. [CrossRef] [PubMed]

2. Yusuf, S.; Zhao, F.; Mehta, S.R.; Chrolavicius, S.; Tognoni, G.; Fox, K.K. Effects of Clopidogrel in Addition to Aspirin in Patients with Acute Coronary Syndromes without ST-Segment Elevation. N. Engl. J. Med. 2001, 345, 494-502. [CrossRef]

3. Mehta, S.R.; Yusuf, S.; Peters, R.J.G.; Bertrand, M.E.; Lewis, B.S.; Natarajan, M.K.; Malmberg, K.; Rupprecht, H.J.; Zhao, F.; Chrolavicius, S.; et al. Effects of Pretreatment with Clopidogrel and Aspirin Followed by Long-Term Therapy in Patients Undergoing Percutaneous Coronary Intervention: The PCI-CURE Study. Lancet 2001, 358, 527-533. [CrossRef]

4. Steinhubl, S.R.; Berger, P.B.; Tift Mann, J.; Fry, E.T.A.; DeLago, A.; Wilmer, C.; Topol, E.J. Early and Sustained Dual Oral Antiplatelet Therapy Following Percutaneous Coronary Intervention: A Randomized Controlled Trial. JAMA 2002, 288, 2411-2420. [CrossRef] [PubMed]

5. Wiviott, S.D.; Braunwald, E.; McCabe, C.H.; Montalescot, G.; Ruzyllo, W.; Gottlieb, S.; Neumann, F.-J.; Ardissino, D.; de Servi, S.; Murphy, S.A.; et al. Prasugrel versus Clopidogrel in Patients with Acute Coronary Syndromes. N. Engl. J. Med. 2007, 357, 2001-2015. [CrossRef] [PubMed]

6. Giustino, G.; Baber, U.; Sartori, S.; Mehran, R.; Mastoris, I.; Kini, A.S.; Sharma, S.K.; Pocock, S.J.; Dangas, G.D. Duration of Dual Antiplatelet Therapy after Drug-Eluting Stent Implantation: A Systematic Review and Meta-Analysis of Randomized Controlled Trials. J. Am. Coll. Cardiol. 2015, 65, 1298-1310. [CrossRef] [PubMed]

7. Ndrepepa, G.; Berger, P.B.; Mehilli, J.; Seyfarth, M.; Neumann, F.J.; Schömig, A.; Kastrati, A. Periprocedural Bleeding and 1-Year Outcome After Percutaneous Coronary Interventions. Appropriateness of Including Bleeding as a Component of a Quadruple End Point. J. Am. Coll. Cardiol. 2008, 51, 690-697. [CrossRef] [PubMed] 
8. Mehran, R.; Pocock, S.J.; Nikolsky, E.; Clayton, T.; Dangas, G.D.; Kirtane, A.J.; Parise, H.; Fahy, M.; Manoukian, S.V.; Feit, F.; et al. A Risk Score to Predict Bleeding in Patients With Acute Coronary Syndromes. J. Am. Coll. Cardiol. 2010, 55, 2556-2566. [CrossRef] [PubMed]

9. Généreux, P.; Giustino, G.; Witzenbichler, B.; Weisz, G.; Stuckey, T.D.; Rinaldi, M.J.; Neumann, F.J.; Metzger, D.C.; Henry, T.D.; Cox, D.A.; et al. Incidence, Predictors, and Impact of Post-Discharge Bleeding After Percutaneous Coronary Intervention. J. Am. Coll. Cardiol. 2015, 66, 1036-1045. [CrossRef] [PubMed]

10. Baber, U.; Dangas, G.; Chandrasekhar, J.; Sartori, S.; Steg, P.G.; Cohen, D.J.; Giustino, G.; Ariti, C.; Witzenbichler, B.; Henry, T.D.; et al. Time-Dependent Associations Between Actionable Bleeding, Coronary Thrombotic Events, and Mortality Following Percutaneous Coronary Intervention: Results From the PARIS Registry. JACC Cardiovasc. Interv. 2016, 9, $1349-1357$. [CrossRef]

11. Valgimigli, M.; Costa, F.; Lokhnygina, Y.; Clare, R.M.; Wallentin, L.; Moliterno, D.J.; Armstrong, P.W.; White, H.D.; Held, C.; Aylward, P.E.; et al. Trade-off Ofmyocardial Infarction vs. Bleeding Types Onmortality after Acute Coronary Syndrome: Lessons from the Thrombin Receptor Antagonist for Clinical Event Reduction in Acute Coronary Syndrome (TRACER) Randomized Trial. Eur. Heart J. 2017, 38, 804-810. [CrossRef] [PubMed]

12. Palmerini, T.; della Riva, D.; Benedetto, U.; Reggiani, B.B.; Feres, F.; Abizaid, A.; Gilard, M.; Morice, M.C.; Valgimigli, M.; Hong, M.K.; et al. Three, Six, or Twelve Months of Dual Antiplatelet Therapy after Des Implantation in Patients with or without Acute Coronary Syndromes: An Individual Patient Data Pairwise and Network Meta-Analysis of Six Randomized Trials and 11 473 Patients. Eur. Heart J. 2017, 38, 1034-1043. [CrossRef] [PubMed]

13. Collet, J.-P.; Thiele, H.; Barbato, E.; Barthélémy, O.; Bauersachs, J.; Bhatt, D.L.; Dendale, P.; Dorobantu, M.; Edvardsen, T.; Folliguet, T.; et al. 2020 ESC Guidelines for the Management of Acute Coronary Syndromes in Patients Presenting without Persistent ST-Segment Elevation. Eur. Heart J. 2021, 42, 1289-1367. [CrossRef]

14. Gragnano, F.; Spirito, A.; Corpataux, N.; Vaisnora, L.; Galea, R.; Gargiulo, G.; Siontis, G.C.M.; Praz, F.; Lanz, J.; Billinger, M.; et al. Impact of Clinical Presentation on Bleeding Risk after Percutaneous Coronary Intervention and Implications for the ARC-HBR Definition. EuroIntervention 2021, 17, e898-e909. [CrossRef]

15. Urban, P.; Mehran, R.; Colleran, R.; Angiolillo, D.J.; Byrne, R.A.; Capodanno, D.; Cuisset, T.; Cutlip, D.; Eerdmans, P.; Eikelboom, J.; et al. Defining High Bleeding Risk in Patients Undergoing Percutaneous Coronary Intervention. Circulation 2019, 140, $240-261$. [CrossRef] [PubMed]

16. Mehran, R.; Rao, S.V.; Bhatt, D.L.; Gibson, C.M.; Caixeta, A.; Eikelboom, J.; Kaul, S.; Wiviott, S.D.; Menon, V.; Nikolsky, E.; et al Standardized Bleeding Definitions for Cardiovascular Clinical Trials: A Consensus Report From the Bleeding Academic Research Consortium. Circulation 2011, 123, 2736-2747. [CrossRef]

17. Costa, F.; van Klaveren, D.; James, S.; Heg, D.; Räber, L.; Feres, F.; Pilgrim, T.; Hong, M.K.; Kim, H.S.; Colombo, A.; et al Derivation and Validation of the Predicting Bleeding Complications in Patients Undergoing Stent Implantation and Subsequent Dual Antiplatelet Therapy (PRECISE-DAPT) Score: A Pooled Analysis of Individual-Patient Datasets from Clinical Trials. Lancet 2017, 389, 1025-1034. [CrossRef]

18. Thygesen, K.; Alpert, J.S.; Jaffe, A.S.; Chaitman, B.R.; Bax, J.J.; Morrow, D.A.; White, H.D.; Mickley, H.; Crea, F.; van de Werf, F.; et al. Fourth Universal Definition of Myocardial Infarction (2018). Eur. Heart J. 2019, 40, 237-269. [CrossRef]

19. Corpataux, N.; Spirito, A.; Gragnano, F.; Vaisnora, L.; Galea, R.; Svab, S.; Gargiulo, G.; Zanchin, T.; Zanchin, C.; Siontis, G.C.M.; et al. Validation of High Bleeding Risk Criteria and Definition as Proposed by the Academic Research Consortiumfor High Bleeding Risk. Eur. Heart J. 2020, 41, 3743-3749. [CrossRef]

20. Natsuaki, M.; Morimoto, T.; Shiomi, H.; Yamaji, K.; Watanabe, H.; Shizuta, S.; Kato, T.; Ando, K.; Nakagawa, Y.; Furukawa, Y.; et al. Application of the Academic Research Consortium High Bleeding Risk Criteria in an All-Comers Registry of Percutaneous Coronary Intervention. Circ. Cardiovasc. Interv. 2019, 12, e008307. [CrossRef] [PubMed]

21. Cao, D.; Mehran, R.; Dangas, G.; Baber, U.; Sartori, S.; Chandiramani, R.; Stefanini, G.G.; Angiolillo, D.J.; Capodanno, D.; Urban, P.; et al. Validation of the Academic Research Consortium High Bleeding Risk Definition in Contemporary PCI Patients. J. Am. Coll. Cardiol. 2020, 75, 2711-2722. [CrossRef]

22. Choi, S.Y.; Kim, M.-H.; Lee, K.-M.; Ko, Y.-G.; Yoon, C.-H.; Jo, M.-K.; Yun, S.-C. Comparison of Performance between ARC-HBR Criteria and PRECISE-DAPT Score in Patients Undergoing Percutaneous Coronary Intervention. J. Clin. Med. 2021, 10, 2566. [CrossRef] [PubMed]

23. Nakamura, M.; Kadota, K.; Nakao, K.; Nakagawa, Y.; Shite, J.; Yokoi, H.; Kozuma, K.; Tanabe, K.; Iijima, R.; Harada, A.; et al. High Bleeding Risk and Clinical Outcomes in East Asian Patients Undergoing Percutaneous Coronary Intervention: The PENDULUM Registry. EuroIntervention 2021, 16, 1154-1162. [CrossRef] [PubMed]

24. Ueki, Y.; Bär, S.; Losdat, S.; Otsuka, T.; Zanchin, C.; Zanchin, T.; Gragnano, F.; Gargiulo, G.; Siontis, G.C.M.; Praz, F.; et al. Validation of the Academic Research Consortium for High Bleeding Risk (ARC-HBR) Criteria in Patients Undergoing Percutaneous Coronary Intervention and Comparison with Contemporary Bleeding Risk Scores. EuroIntervention 2020, 16, 371-379. [CrossRef]

25. Gimbel, M.; Qaderdan, K.; Willemsen, L.; Hermanides, R.; Bergmeijer, T.; de Vrey, E.; Heestermans, T.; Tjon Joe Gin, M.; Waalewijn, R.; Hofma, S.; et al. Clopidogrel versus Ticagrelor or Prasugrel in Patients Aged 70 Years or Older with NonST-Elevation Acute Coronary Syndrome (POPular AGE): The Randomised, Open-Label, Non-Inferiority Trial. Lancet 2020, 395, 1374-1381. [CrossRef] 
26. James, S.; Åkerblom, A.; Cannon, C.P.; Emanuelsson, H.; Husted, S.; Katus, H.; Skene, A.; Steg, P.G.; Storey, R.F.; Harrington, R.; et al. Comparison of Ticagrelor, the First Reversible Oral P2Y12 Receptor Antagonist, with Clopidogrel in Patients with Acute Coronary Syndromes: Rationale, Design, and Baseline Characteristics of the PLATelet Inhibition and Patient Outcomes (PLATO) Trial. Am. Heart J. 2009, 157, 599-605. [CrossRef] [PubMed]

27. Gimbel, M.E.; Tavenier, A.H.; Bor, W.; Hermanides, R.S.; de Vrey, E.; Heestermans, T.; Gin, M.T.J.; Waalewijn, R.; Hofma, S.; den Hartog, F.; et al. Ticagrelor Versus Clopidogrel in Older Patients with NSTE-ACS Using Oral Anticoagulation: A Sub-Analysis of the POPular Age Trial. J. Clin. Med. 2020, 9, 3249. [CrossRef] [PubMed]

28. Qaderdan, K.; Ishak, M.; Heestermans, A.A.C.M.; de Vrey, E.; Jukema, J.W.; Voskuil, M.; de Boer, M.J.; Van'T Hof, A.W.J.; Groenemeijer, B.E.; Vos, G.J.A.; et al. Ticagrelor or Prasugrel versus Clopidogrel in Elderly Patients with an Acute Coronary Syndrome: Optimization of Antiplatelet Treatment in Patients 70 Years and Older-Rationale and Design of the POPular AGE Study. Am. Heart J. 2015, 170, 981-985.e1. [CrossRef]

29. Costa, F.; van Klaveren, D.; Feres, F.; James, S.; Räber, L.; Pilgrim, T.; Hong, M.K.; Kim, H.S.; Colombo, A.; Steg, P.G.; et al. Dual Antiplatelet Therapy Duration Based on Ischemic and Bleeding Risks After Coronary Stenting. J. Am. Coll. Cardiol. 2019, 73, 741-754. [CrossRef]

30. Hahn, J.Y.; Song, Y.B.; Oh, J.H.; Chun, W.J.; Park, Y.H.; Jang, W.J.; Im, E.S.; Jeong, J.O.; Cho, B.R.; Oh, S.K.; et al. Effect of P2Y12 Inhibitor Monotherapy vs Dual Antiplatelet Therapy on Cardiovascular Events in Patients Undergoing Percutaneous Coronary Intervention: The SMART-CHOICE Randomized Clinical Trial. JAMA 2019, 321, 2428-2437. [CrossRef]

31. Hahn, J.Y.; Song, Y.B.; Oh, J.H.; Cho, D.K.; Lee, J.B.; Doh, J.H.; Kim, S.H.; Jeong, J.O.; Bae, J.H.; Kim, B.O.; et al. 6-Month versus 12-Month or Longer Dual Antiplatelet Therapy after Percutaneous Coronary Intervention in Patients with Acute Coronary Syndrome (SMART-DATE): A Randomised, Open-Label, Non-Inferiority Trial. Lancet 2018, 391, 1274-1284. [CrossRef]

32. Mehran, R.; Baber, U.; Sharma, S.K.; Cohen, D.J.; Angiolillo, D.J.; Briguori, C.; Cha, J.Y.; Collier, T.; Dangas, G.; Dudek, D.; et al. Ticagrelor with or without Aspirin in High-Risk Patients after PCI. N. Engl. J. Med. 2019, 381, 2032-2042. [CrossRef] [PubMed]

33. Escaned, J.; Cao, D.; Baber, U.; Nicolas, J.; Sartori, S.; Zhang, Z.; Dangas, G.; Angiolillo, D.J.; Briguori, C.; Cohen, D.J.; et al. Ticagrelor Monotherapy in Patients at High Bleeding Risk Undergoing Percutaneous Coronary Intervention: TWILIGHT-HBR. Eur. Heart J. 2021, 42, 4624-4634. [CrossRef] [PubMed]

34. Baber, U.; Dangas, G.; Angiolillo, D.J.; Cohen, D.J.; Sharma, S.K.; Nicolas, J.; Briguori, C.; Cha, J.Y.; Collier, T.; Dudek, D.; et al. Ticagrelor Alone vs.Ticagrelor plus Aspirin Following Percutaneous Coronary Intervention in Patients with Non-ST-Segment Elevation Acute Coronary Syndromes: TWILIGHT-ACS. Eur. Heart J. 2020, 41, 3533-3545. [CrossRef] [PubMed]

35. Valgimigli, M.; Frigoli, E.; Heg, D.; Tijssen, J.; Jüni, P.; Vranckx, P.; Ozaki, Y.; Morice, M.-C.; Chevalier, B.; Onuma, Y.; et al. Dual Antiplatelet Therapy after PCI in Patients at High Bleeding Risk. N. Engl. J. Med. 2021, 385, 1643-1655. [CrossRef]

36. Watanabe, H. STOPDAPT-2 ACS: One-Month Dual Antiplatelet Therapy Followed by Clopidogrel Monotherapy in Acute Coronary Syndrome. In Proceedings of the European Society of Cardiology Virtual Congress, London, UK, $27-30$ August 2021. 